\title{
Qualitative Assessment of the Learning Outcomes of an International Service Learning Project in Civil Engineering
}

\author{
Ann E. Jeffers \\ Assistant Professor \\ Civil and Environmental Engineering \\ University of Michigan \\ jffrs@umich.edu
}

\author{
Paul A. Beata \\ Graduate Student \\ Civil and Environmental Engineering \\ University of Michigan \\ pbeata@umich.edu
}

\author{
Beverly Strassmann \\ Professor \\ Anthropology \\ University of Michigan \\ bis@umich.edu
}

\begin{abstract}
A qualitative study was performed to determine the learning outcomes of an international service learning project in civil engineering. The university program involves the student-led design and construction of suspended pedestrian bridges in rural Bolivia. Five students traveled to Bolivia for a period of four weeks to oversee the construction of a bridge. The students were asked to keep reflective journals that were guided by a series of writing prompts. We analyzed the qualitative data within a phenomenological framework, which allowed common themes to be identified from the data. The measured learning outcomes include technical competency, adaptability, creativity, global competency, crosscultural communication skills, and teamwork and interpersonal communication skills. The data are examined in relation to relevant literature and supporting quotes from the students' journals are provided. Our findings support the ideas that international service learning experiences in engineering strengthen global competency and communication, improve mastery of technical skills, and instill an understanding of the social context of engineering work. Additionally, complications that arose in the field taught the students adaptability, which is defined here as the ability to modify an engineering design to meet the constraints imposed in the field. As a result of our analysis, we propose reflection questions that allow the assessment of technical and non-technical learning outcomes.
\end{abstract}

Index Terms - Service learning, civil engineering, qualitative research, phenomenological framework

\section{INTRODUCTION}

Today's rapidly advancing technological environment and increasingly global economy has prompted a widespread call for reform in engineering education. ${ }^{1}$ As a result, engineering programs have placed greater emphasis on active, experiential, problem-based, and team-based learning. While the call for reform has resulted in significant changes in the manner in which engineering is taught, the literature shows that the current model for engineering education continues to fall short in preparing engineering graduates to tackle the challenges of the 21st century. ${ }^{2}$ Evidence suggests that engineers are particularly in need of better developed "soft 
skills," which encompass communication and leadership skills as well as social, economic, and environmental awareness. ${ }^{3}$

To address this limitation, there have been significant efforts in recent years to incorporate service learning in engineering curricula. ${ }^{4,5}$ Service learning is a pedagogy that emphasizes experiential learning through structured community service. The partnership between the academic institution and the community is founded on a mutually beneficial relationship that provides learning experiences for students while satisfying real needs within the community. Reflection is central to service learning because it instills a deeper understanding of the social context of the work. ${ }^{6}$ Service learning bridges the technical and social realms of engineering and therefore addresses a number of shortcomings in traditional engineering pedagogies. In particular, service learning projects strengthen proficiency in domain-specific concepts (e.g., ${ }^{7,8}$ ). The extent of learning is aided by the fact that the projects are inductive and based on real-world problems. ${ }^{4}$ Research on problem-based learning has shown that real-world problems increase motivation and satisfaction, foster problem-solving skills, cultivate extensible and flexible knowledge bases, and promote long-term retention and motivation for life-long learning. ${ }^{9-16}$ The service-learning projects are team-based and involve interactions between students and members of the community, which additionally promote the development of interpersonal and collaborative skills.

Service learning projects may be carried out in an international setting, which adds another dimension of learning. Research has shown that international experiences in general promote cultural sensitivity, the development of a global perspective, the development of communication skills, the development of problem-solving skills, and the ability to adapt to an unfamiliar environment. ${ }^{17-19}$ While it is accepted that global experiences are important for personal and professional development, there is presently limited data regarding the learning outcomes of international service-learning experiences in engineering, particularly for learning outcomes that exist outside of the ABET criteria, such as intercultural proficiency and customer satisfaction. ${ }^{20}$ Budny and Gradoville ${ }^{21}$ performed an assessment of an international capstone design project by having the students rank the importance of various technical and non-technical components of the project. They found that the students developed an appreciation for the local lifestyle, improved their communication skills, learned to work with limited data, gained knowledge of local construction practices, and learned to work with a client. Mohtar and Dare ${ }^{18}$ defined twelve learning outcomes associated with global competency that they categorized as global technical skills, global professional skills, and global social-cultural (i.e., interpersonal) skills. The learning outcomes were used to assess the Global Design program at Purdue University using quantitative and qualitative methods. In these cases, the learning outcomes were correlated to (rather than based on) the ABET learning outcomes.

While the use of service learning in engineering is becoming increasingly common and has obvious educational benefits, there are limitations in the nature and scope of projects that can be established between universities and community partners. In civil engineering, for example, realworld infrastructure projects (e.g., bridges, buildings, and dams) are often too vast in size and cost to be scaled into meaningful service projects that could reasonably be carried out by undergraduate design teams. Consequently, the bulk of service learning projects that are reported in the literature focus on other facets of civil engineering, involving experiences such as transportation studies, soil analyses, post-hazard assessments, and various issues of water supply and treatment ${ }^{21-23}$. 
To meet the demand for service learning in civil engineering, a service learning program was instituted at the University of Michigan that engages multidisciplinary teams of students in the design and construction of pedestrian bridges in rural Bolivia. The program involves a close collaboration with Bridges to Prosperity, a non-profit organization that specializes in the design and construction of inexpensive and locally sustainable pedestrian bridges in rural communities. Similar partnerships exist at other institutions through the Bridges to Prosperity University Program. Such programs encompass ideal service learning experiences because the bridge design/build projects are at the appropriate skill level for undergraduate engineering students, they embody a comprehensive civil engineering design experience, the projects are real-world and hands-on, they involve multidisciplinary teams of students, they have an international focus, and they have suitable timeline and cost to be carried out by a team of students.

The University of Michigan Bridges to Prosperity program was instituted as a voluntary (i.e., extra-curricular) student organization in 2012, and the first student-led project was completed in 2013. In conjunction with the students' first project, we performed a qualitative study to assess the technical and non-technical learning outcomes associated with the design and construction of a suspended pedestrian bridge in an international setting. We specifically considered the following research questions in the study:

- To what degree did the project advance the students' mastery of technical concepts?

- How did complexities (e.g., linguistics, local construction practices, diverse social and cultural environment) related to the site affect students' perceptions of engineering design/construction, particularly within a global and social context?

- How did the experience affect the students' confidence in tackling unpredictable and illposed engineering problems?

- How did the project affect the students' abilities to function in multidisciplinary teams?

- What communication skills were strengthened as a result of the project?

This paper expands upon the preliminary analysis by Author ${ }^{24}$ which focused primarily on learning outcomes related to technical competency and teamwork. Here, we consider adaptability, creativity, global competency, and cross-cultural communication as independent learning outcomes, and we explore global competency and cross-cultural communication in greater depth. Our discussion considers the factors that affected the extent of learning that was observed in the study, and we propose revised reflection questions that explicitly seek to measure the learning outcomes related to non-technical skills (i.e., adaptability, global competency, crosscultural communication, and interpersonal communication/teamwork) as well as technical skills.

\section{CONTEXT}

The Bridges to Prosperity student chapter at the University of Michigan designed and constructed its first pedestrian bridge in central Bolivia in 2013. The Bridges to Prosperity NGO assisted the students with identifying the bridge site, establishing the construction contract with the community, coordinating labor contributions from the community, and procuring materials for the bridge. Students designed the bridge during the academic year according to the design manuals published by Bridges to Prosperity ${ }^{25}$, and a team of five students traveled to the site for four weeks to oversee the construction of the bridge. During their four-week stay in Bolivia, the 
students were asked to keep reflective journals that were guided by a series of weekly writing prompts.

The bridge was a suspended pedestrian bridge (Fig. 1) that was approximately thirty meters in length and spanned a river. The construction process involved: (1) excavation, (2) construction of the tiers and towers, (3) installation of the anchors and cable, (4) setting the cable sag, (5) construction of the approaches, and (6) installation of the fencing and decking. Prior to the students' arrival in Bolivia, Bridges to Prosperity coordinated the majority of the excavation as well as the tier and tower construction. The students were responsible for working with the community to accomplish the remainder of the construction tasks and for ensuring quality control during all phases of construction. Prior to the students' arrival on site, the tier and tower construction had been completed and the anchor holes had been excavated.

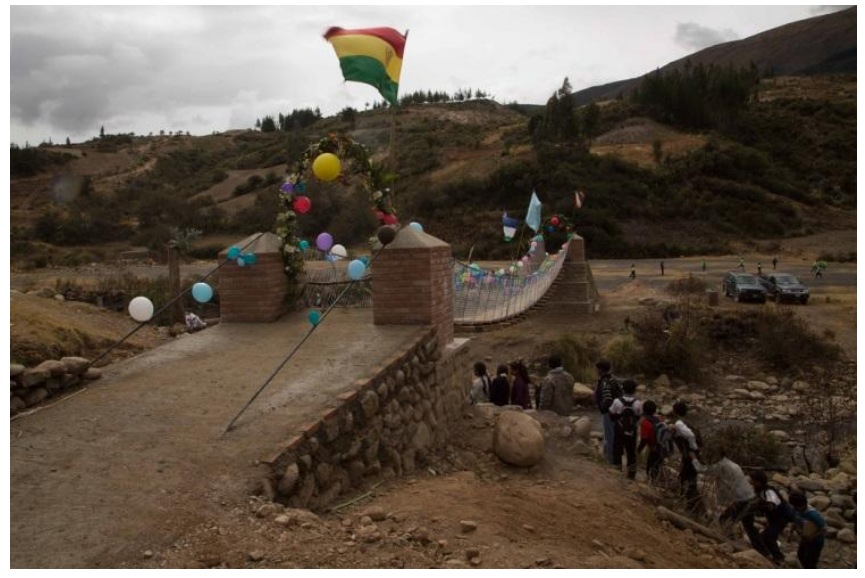

FIGURE 1

PHOTOGRAPH OF THE COMPLETED BRIDGE

The project involved several deviations from the design conditions that required the students to adapt the design to the field conditions. For example, the project required two weeks of additional excavation to place the anchor holes at the correct locations. A different type of cable was shipped to the site than anticipated, which required a significant modification of the bridge design. Additionally, the soil conditions did not allow excavation to the specified depth. Modifications to the design were based on hand calculations in the field and engineering judgment and required approval from Bridges to Prosperity. Despite deviations from the original construction plans, the project finished on schedule.

Trained engineers from Bridges to Prosperity were available onsite to help the students resolve problems in the field and to oversee critical construction tasks. Additionally, an engineering professional was onsite for approximately one week to oversee the cable installation, which was the most important and challenging construction task. Despite having guidance from experienced engineers, the students assumed the leadership of the project, and therefore were responsible for ensuring the proper construction of the bridge and keeping the project on schedule. 


\section{Participants}

\section{METHODOLOGY}

Five students voluntarily traveled to the site in Bolivia to work alongside the community and to oversee the construction of the bridge. The team of students included four civil engineering students and one non-engineering student who was fluent in Spanish. One of the students was a graduate student, and the remaining students were upper-division undergraduate students (i.e., juniors and seniors). Four out of the five students participated in the study (i.e., $n=4$ ). The students who traveled to Bolivia cited two primary reasons for participating in the bridge construction project:

- A desire to participate in a real-world engineering project

- A desire to use professional skills and knowledge to address a significant need in an underprivileged community

\section{Data Collection}

We asked the students to keep reflective journals during their time in Bolivia. Writing prompts were provided to generate reflection while eliciting responses that would answer our research questions. We devised the reflection questions to measure the expected learning outcomes, and we timed the questions to coincide with major milestones in the construction schedule, as shown in Table I. Specifically, we sought to assess technical skills, teamwork, communication skills, global competency, and personal and professional growth. We also looked for evidence of the students being able to overcome social, cultural, and communication barriers and being able to tackle unpredictable and ill-posed engineering problems. 
International Journal for Service Learning in Engineering, Humanitarian Engineering and Social Entrepreneurship Vol. 10, No. 1, pp. 38-58, Spring 2015

ISSN 1555-9033

TABLE I

REFLECTION QUESTIONS CORRESPONDING TO EXPECTED LEARNING OUTCOMES

\begin{tabular}{|c|c|c|}
\hline Timing & Question & Expected Outcomes \\
\hline Pre-trip & $\begin{array}{l}\text { 1. Why is this project important to you? } \\
\text { 2. What personal and professional goals have you set for } \\
\text { yourself for this trip? What do you hope to get out of this } \\
\text { experience? } \\
\text { 3. What are the greatest challenges that you foresee in carrying } \\
\text { out the project? }\end{array}$ & $\begin{array}{l}\text { Understanding motivation and } \\
\text { preconceived notions about } \\
\text { the project }\end{array}$ \\
\hline Week 1 & $\begin{array}{l}\text { 4. Describe the apparent challenges that Bolivia faces in regards } \\
\text { to the creation and maintenance of infrastructure (e.g., roads, } \\
\text { buildings, power/water supply). You can frame your } \\
\text { response in terms of construction techniques, the amount and } \\
\text { type of resources available, the quality of construction, etc. } \\
\text { 5. What are your initial impressions of Bolivian culture and } \\
\text { lifestyle, particularly in the communities that you are } \\
\text { working closely with? }\end{array}$ & $\begin{array}{l}\text { Overcoming social, cultural, } \\
\text { communication barriers }\end{array}$ \\
\hline Week 2 & $\begin{array}{l}\text { 6. Describe your interactions with the community members, } \\
\text { including positive and negative experiences. What challenges } \\
\text { have you encountered in regards to communication and/or } \\
\text { reaching consensus on important construction tasks, and how } \\
\text { were these challenges overcome? }\end{array}$ & $\begin{array}{l}\text { Overcoming social, cultural, } \\
\text { communication barriers } \\
\text { Engineering in a global context } \\
\text { Teamwork }\end{array}$ \\
\hline Week 3 & $\begin{array}{l}\text { 7. What have been the most challenging construction tasks so } \\
\text { far? Were there any differences between how you planned } \\
\text { the construction vs. how it was actually executed in the field? }\end{array}$ & $\begin{array}{l}\text { Tackling unpredictable, ill- } \\
\text { posed engineering problems } \\
\text { Engineering in a global context }\end{array}$ \\
\hline Week 4 & $\begin{array}{l}\text { 8. Reflect on your initial impressions of Bolivian culture and } \\
\text { lifestyle from your first week in the country. How have your } \\
\text { impressions evolved over your time in Bolivia? }\end{array}$ & $\begin{array}{l}\text { Overcoming social, cultural, } \\
\text { communication barriers }\end{array}$ \\
\hline & $\begin{array}{l}\text { 9. Describe your greatest success (or successes) during the } \\
\text { project's execution. How did it make you feel? How did your } \\
\text { team react? How did the community members react? }\end{array}$ & $\begin{array}{l}\text { Tackling unpredictable, ill- } \\
\text { posed engineering problems } \\
\text { Teamwork }\end{array}$ \\
\hline Post-trip & $\begin{array}{l}\text { 10. Reflect on your responses to the pre-trip questions regarding } \\
\text { the importance of the project, your personal and professional } \\
\text { goals, and the challenging aspects of the project. Have your } \\
\text { views changed from your prior responses (e.g., would you } \\
\text { change any of your previous responses)? } \\
\text { 11. Summarize what you have learned from the experience of } \\
\text { constructing a bridge in Bolivia. What new technical and } \\
\text { interpersonal skills have you developed? What knowledge or } \\
\text { understanding do you hope to retain in the future? }\end{array}$ & $\begin{array}{l}\text { Personal and professional } \\
\text { growth } \\
\text { Supporting evidence for } \\
\text { measured outcomes }\end{array}$ \\
\hline
\end{tabular}

Along with the questions in Table I, the students were given the following guidance in keeping their reflective journals:

Enclosed are a series of writing prompts to be completed over the course of your trip to Bolivia. There is no specified word limit (maximum or minimum) for each question. However, it is expected that typical responses will range from 250-500 words per question. When answering each question, reflect on your experiences, be as specific as possible in writing your response, and try to include examples (when possible) to illustrate a point. 


\section{Data Analysis}

We analyzed the writing prompts within a phenomenological framework ${ }^{26}$, which allowed common themes to be identified from the reflective journals. The analysis involved the identification of words and phrases (i.e., "individual natural units") that corresponded to meaningful learning experiences, rereading each unit with "openness" and identifying the central theme for the unit, evaluating the data systematically in regards to the research questions, and clustering the experiences into broader (i.e., "revelatory") themes ${ }^{27,28}$. The themes were then examined in the context of relevant literature and the findings supported by quotes from the participating students. While our research was guided by the aforementioned research questions, we did not seek to eliminate data that did not fit within the research questions, i.e., we approached the data with "openness." For example, while we did not explicitly seek to measure creativity as a learning outcome, data regarding creativity emerged from the students' journals. Therefore, creativity is included here as a measured learning outcome. To ensure trustworthiness of the results, two of the authors independently performed thematic analysis of the data and cross-checked their findings. The participants of the study were also asked to review the findings of our study.

\section{RESUlTS}

The learning outcomes were clustered into the following major themes:

1. Technical skills

2. Adaptability

3. Creativity

4. Global competency

5. Cross-cultural communication skills

6. Teamwork and interpersonal communication skills

The broad themes are given in Table II along with constituent themes that were derived from the individual natural unit analysis. We build upon the preliminary work by Author ${ }^{24}$ but have modified the learning outcomes to treat adaptability, creativity, global competency, and crosscultural communication as separate learning outcomes. 


\section{TABLE II}

LEARNING OUTCOMES FROM THEMATIC ANALYSIS

\begin{tabular}{|c|c|}
\hline Learning Outcome & Constituent Themes \\
\hline Technical skills & $\begin{array}{l}\text { Quality control, safety, engineering tolerances, sense of scale, keeping to a } \\
\text { schedule, understanding factors of safety, reading construction drawings, } \\
\text { excavation/foundation construction, mixing/pouring concrete, building } \\
\text { rebar cages, constructing a rock wall, using power tools, using Abney } \\
\text { levels, and using safety harnesses }\end{array}$ \\
\hline Adaptability & $\begin{array}{l}\text { Performing engineering calculations in the field, making decisions, adapting } \\
\text { the design to site conditions }\end{array}$ \\
\hline Creativity & Group-level innovation \\
\hline Global competency & $\begin{array}{l}\text { Global perspective regarding civil infrastructure, understanding of Bolivian } \\
\text { culture, appreciation of and tolerance for life without modern } \\
\text { conveniences }\end{array}$ \\
\hline $\begin{array}{l}\text { Cross-cultural } \\
\text { communication skills }\end{array}$ & $\begin{array}{l}\text { Communication across different languages, resolving differences in work } \\
\text { habits }\end{array}$ \\
\hline $\begin{array}{l}\text { Teamwork/interpersonal } \\
\text { communication skills }\end{array}$ & Conflict resolution, interdependence \\
\hline
\end{tabular}

\section{Technical Skills}

The students gained practical experience in construction that is generally not addressed in civil engineering coursework, although it sometimes is addressed through internship experiences. When asked to summarize what they learned from the bridge-building experience, the students reported learning "how to mix concrete in large quantities, how to build a rock wall, how to build a foundation, how to use an Abney level, how to level the bridge cables, how to build rebar cages, how to work with power tools to build the deck of the bridge, working with a harness suspended up in the air," as well as how to "read construction drawings and design specifications," and "proper construction and purpose of a rock wall." These tangible skills are to be expected due to the construction tasks that were involved. However, we believe that the hands-on nature of the project allowed the students to develop an appreciation for scale and engineering tolerances that had not been previously developed in the classroom. This was particularly evident in the excavation of the anchor holes, which were dug by hand due to the lack of excavation equipment. As described by one student,

I also had a wakeup call with how deep holes really are. All through college I would design something and call out a certain depth; now I know the effort that goes into digging something that deep! A $2 m$ deep hole is enormous when you dig by hand! Before, it seemed like such a small amount.

The students also had realizations that it is not always possible to build to the exact dimensions specified in the construction plans. For example, one student stated that the act of building a rebar cage by hand taught him "that it is very difficult to get everything to the correct dimensions!"

The challenging site conditions gave students an opportunity to learn about the factors of safety that are built into the design manuals. For example, the design manuals called for anchor 
holes that were four meters deep based on the loads and dimensions of the superstructure, yet the students were only able excavate two meters due to the limitations of hand tools (i.e., shovels and pick axes). When the Bridges to Prosperity engineer appeared on site, she stated that the two-meter deep anchor holes were adequate, which seemed to surprise the students. After some discussion, the students learned that the specifications in the design manuals were overly conservative. In response, one student noted, "The B2P design guidelines for dirt coverage were not hard and fast at 3 meters. So even if our bridge was $40 \mathrm{~m}$ long, a $2.5 \mathrm{~m}$ hole would have most likely been okay." In regards to the modified depth of the anchor holes, another student stated,

I think the problem lies in the accounting of people standing shoulder to shoulder in regards to the load the bridge must withstand. There must be factors of safety built in, but people will not STAND shoulder [to shoulder] on the bridge. It is a bridge used for passage and I think the most amount of people we have seen on the current bridge at one time is 5. ... [The Bridges to Prosperity staff member] suggested we redo our calculations in our meetings back home and calculate the horizontal and vertical forces of the holes being $2 m$ (excluding anchor space) and make sure we see the safety of it.

Rather than waiting until they returned to the U.S., the students performed the calculations in the field to verify the safety of the modified design. Thus, the students learned how to modify the design while ensuring safety of the construction by taking into account the appropriate factor of safety.

\section{Adaptability}

The differences between the field conditions and the original bridge design provided numerous opportunities for the students to learn how to modify the design based on constraints imposed by the site, which we term adaptability. An example can be seen in the excavation of the anchor holes, which were placed five meters from the design locations prior to the students' arrival. One student described the situation as follows:

The construction plans had the exact position of the anchor holes laid out-approximately $13 m$ from the rear face of the tier to the back of the hole. The placement of the anchors was critical to ensure that the load on the cables did not pull the anchors out of the ground. When we arrived at the bridge site, the holes were dug in the wrong place! Also, the manual stated that for a bridge spanning $30 \mathrm{~m}$ to $60 \mathrm{~m}$ there needed to be $3 \mathrm{~m}$ of cover. The anchor was $1 \mathrm{~m}$ tall, so that meant we needed a four meter deep hole...on both sides!! On day one we were struck with panic!

The students clearly recognized the deviation from the design and justified their concern by acknowledging the importance of proper anchor construction to the safety of the bridge. Another student commented on the team's course of action:

We asked [a Bridges to Prosperity engineer] what we should do about it and her response was "you're the engineers; you can decide what to do." So, we ran a few calculations and decided that we needed the excavation to be where we originally intended it to be to achieve 
an acceptable margin of safety. So we had the community fill in the hole and dig a new hole 5 meters away (excavation for the anchor cage).

In the face of an unexpected problem in the field, the students initially "panicked" and sought advice from a Bridges to Prosperity engineer. However, the engineer gave the students an opportunity to learn from the experience by placing the decision in the students' hands. The students demonstrated sound engineering judgment by checking the safety of the existing condition. They recognized that the decision to dig new anchor holes required two additional weeks of labor and would delay subsequent construction tasks. However, the students knew that it was necessary to ensure the safety of the bridge. The Bridges to Prosperity engineer verified that the students' decision was an appropriate course of action. In this manner, the students were able to make an important decision under the guidance of a more senior engineer.

When the students were unable to dig the anchor holes to the design depth due to the soil conditions and limitations of the hand tools, another opportunity emerged for learning how to adapt the design to the field conditions. Specifically, the students were asked to redo their calculations in the field to determine the forces in the cables with the modified two-meter deep anchor hole and to verify the safety of the design. Rather than employ a less conservative design, the students were able to increase the safety of the shallow anchor holes by extending the approach walls to cover the anchors, as described by one student:

The holes were not dug to our original specifications, either. We strengthened the horizontal resisting force against the anchors by building the approach walls to up to the concrete anchors. This way, if the anchor wanted to pull out, it would have to move the massive rock wall that we so expertly hand crafted!! This will never happen! The cables were at an angle such that the anchors would not be able to pull out in the vertical direction with the amount of soil that was on top of the anchors.

Because the students had no prior field engineering experience, this was their first opportunity to learn how to adapt a design to the field conditions. Adaptability, in the context of engineering design, requires an understanding of the constraints of the site, the ability to perform engineering calculations to justify an action, and the confidence to execute the plan. Initially the students lacked confidence in their ability to modify the design to satisfy the constraints in the field (e.g., the students "panicked" upon arrival at the site). However, the Bridges to Prosperity engineer guided the students to the correct course of action, teaching the students how to modify the design and to verify the safety of the modified design using engineering knowledge. One student reflected on the learning experience as follows:

There is so much of the bridge building process that you can't prepare for in the classroom, so you just get out there and do the best you can. I think I learned that $90 \%$ of what we did we just learned on the fly from [the Mason], [the Bridges to Prosperity engineer], and even each other. Each bridge is different and each site has its own challenges, so the only thing to do is to be constantly thinking of what the task at hand is and if there is any way to improve $i t$. The work we did required about $30 \%$ classroom knowledge and $70 \%$ just common sense and physics laws. Each are important and it was a good mix. 


\section{Creativity}

Difficult construction tasks gave students an opportunity to demonstrate creativity, e.g., to improve the efficiency of the construction process. For example, one student described a system that was devised to lift dirt out of the anchor holes:

...digging at that depth became difficult because it was a great distance to lift a shovel. We eventually developed a system in which we used buckets to haul the dirt out - we had 2 people in the hole digging/pick axing and filling buckets with the dirt/soil and 2 people at the top of the excavation pulling the buckets out of the excavation and depositing them onto a dirt pile.

Another student mentioned similar innovations in the construction process such as "jumping on cross beams to weight them down" during the decking installation. Teamwork appeared to be an integral component of the innovations in the field, as elaborated on in the section on Teamwork and Interpersonal Communication Skills.

\section{Global Competency}

The project was carried out in an international setting and required the students to work closely with the locals, thus creating an environment for cultivating global competency. Global competency in engineering is defined by Downey et al. ${ }^{19}$ as the attainment of "knowledge, ability, and predisposition to work effectively with people who define problems differently." Global competency requires an understanding of the similarities and differences of people from different countries, the ability to analyze how the value of engineering by people from different countries is affected by their lives and experiences, and a predisposition to appreciate and respect the different knowledge, skills, and perspectives that people from different countries can bring to an engineering project. ${ }^{19}$ In the bridge construction project, the juxtaposition of resources and lifestyles between Bolivia and the U.S. provided a rich opportunity for cultivating global competency. In their responses to the Week 1 questions, the students noted that the quality of infrastructure was affected significantly by geographical impediments (e.g., the country being mountainous and landlocked) and resource limitations (e.g., availability of construction materials) as well as political restrictions (e.g., import laws). One student described the infrastructure limitations as follows:

The roads that go through the mountains are built for one purpose, functionality. There appears to be (have been) limited consideration given to safety when these roads were built. There are sharp, tight turns around the mountain edges and no safety features (like guardrails) present. There is hardly any room for two cars to pass each other, although the roads along the mountain ridges are not limited to one way traffic. I think geography here plays a large role to the poor quality of the rural roads just because it makes the creation of better roads more costly and difficult to construct.

In the response given above, the student acknowledged the differences in infrastructure between Bolivia and the U.S. but also considered the geographical and resource limitations that led to the 
state of infrastructure, which indicates a deeper level of understanding. Similar types of responses were provided by the other students, indicating that reflection may help foster global competency in students participating in similar engineering experiences.

In their responses to questions about the infrastructure and interactions with members of the community, the students frequently drew comparisons between the U.S. and Bolivia. However, one student noticed in Week 1 that evaluating Bolivian infrastructure according to U.S. standards was inconsistent with the ways that Bolivians view their infrastructure, as can be seen in the following quote:

Bolivia is not a rich country by any means but it seems as if they have everything they need. I am basing this off the fact that the community members said that how people live in [the village where the bridge was being constructed], is how most of rural Bolivia lives. So this is a tough question to answer because the people in the town do not see their infrastructure as a challenge. But, I see many things wrong when comparing to the U.S.

Another student had a similar revelation towards the end of the trip:

I think I was initially and subconsciously comparing everything in Bolivia to its American counterpart. Bolivians obviously don't do that because a.) they don't know anything else and b.) not all of the world needs to be compared to American standards.

These statements indicate that the students recognized perspectives that were different from their own and realized that engineering work (i.e., infrastructure) holds different value to people living within different circumstances. As one student stated, "I also was able to gain a more global perspective on the needs for infrastructure development. Before, I think it was just something I had read about and knew there was a need for it, but it became more real to me during this trip." Another student remarked, "I will never take infrastructure here, or anywhere, for granted because a lot of work, planning, and effort is required."

\section{Cross-Cultural Communication}

We found that language barriers and cultural differences provided important learning experiences for the students in regards to cross-cultural communication skills. The bridge site was located in a rural Bolivian town where the primary language is Quechua, although many of the community members were fluent in Spanish as well. The students therefore had to communicate in Spanish, and the only student who was fluent in Spanish was a non-engineer. As described in one student's journal, the chain of communication involved (1) the engineering students telling the non-engineering student what needed to be done, (2) the non-engineering student communicating the task to a designated community member in Spanish, and (3) the designated community member communicating the task to other members of the community in Quechua. One student described the challenges posed by the language barrier as, "I feel like we both end up nodding about things [when] we don't really understand what we are communicating." The language barrier hindered some of the construction tasks, for example, in the setting of the cable sag. Nonetheless, in the post-trip questions, most students reported that their communication skills were strengthened as a result of the experience. 
In addition to the language barriers, the students had to resolve cultural differences in working with members of the community, particularly related to differences in work habits. For example, the students frequently mentioned the long coca breaks taken by the community members every morning and afternoon. A student described the situation at the site as follows:

At the worksite all of the men and women come ready to work. There are supposed to be 8 community members working with us each day, but usually there are only 4-5. ... Men and women, old and young show up and work very hard. They are much better/stronger at taking big rock out of the soil and also probably work a lot faster than us. We tend to work for 2025 minutes, get winded and take a 5 minute break and begin again. The community members can work upwards of 45-60 minutes without a break, but then take a 20-30 minute break and most of them chew coca leaves during their breaks.

One student described his frustrations with the long breaks taken by the locals, which he initially interpreted as indifference to the bridge being built rather than a cultural difference. However, after working alongside the community members for a few days, he realized that the locals were more skilled at digging and had greater endurance than the students. In the end, he concluded, "However, this was silly of me to get frustrated. ... This was a cultural barrier I had to get over." This incident also highlights a shift in global competency, from believing that there is only one right way of doing things to recognizing that different approaches may have significant value.

Over time, the communication barriers between the students and community dissolved and the students were able to work collaboratively with the community. For example, one student reflected on the final day of construction:

While the mason poured concrete on one side, we and the community members backfilled the other approach with small rocks and sand. Even young children helped carry small rocks and fill buckets with sand. The excitement of having the bridge almost complete stirred everyone to pitch in. We had to work until after dark in order to finish pouring the concrete but it was awesome to know that our bridge was done and we would celebrate the next day. One community member brought chicha (a fermented corn drink for celebrations) and passed it around when we were done. We and several community members wrote our names in the fresh concrete.

It was satisfying to be done with our beautiful bridge but it added to the excitement that we had to rush to bring it together at the end. Moreover, we were sometimes working separately from the community, with them working on some small project and us on another. I'm glad that we ended it with us and the community so clearly side by side and working hard.

The collaboration between the students and community was aided by the fact that the two parties were working towards a common goal and interdependence was high, i.e., the community relied on the engineering expertise of the students while the students relied on the community for expertise in local construction practices and labor. Additionally, the community helped to cultivate trust by including the students in community activities such as a holiday ceremony and informal volleyball and soccer matches. 


\section{Teamwork and Interpersonal Communication Skills}

We assessed teamwork using the constructs proposed by Borrego et al., ${ }^{29}$ namely, shared mental models, interdependence, trust, conflict, and social loafing. Shared mental models were fostered prior to the students' travel to Bolivia through a series of pre-trip meetings between the students, the faculty advisor of the student chapter, and engineers from Bridges to Prosperity. In these meetings, the students developed a common set of goals to be accomplished during the trip, created a detailed construction schedule with contingency plans, designated leaders for each construction task, and discussed and planned for various scenarios that might be encountered in the field. We found that interdependence was high, which was likely due to the complex and high-stakes nature of the project. For example, quality control naturally required certain team members to check the work of others, which was described by one student as follows:

[B] efore we could back fill you must be $100 \%$ sure of your anchors work because if you aren't there is no going back. Our group responded well to ensuring the small details that would ensure the safety of the bridge. Some examples are well-placed and well-rodded concrete around anchors, all clamps tightened to at least $25 \%$ reduction, and backfilling with all different size rocks and particles. We relied on each other to double check each others work throughout these steps. For example, [one student] and I would set the clamps at their appropriate distances and then have [two other students] check to make sure they looked straight and even and then we would tighten them.

The challenging construction tasks provided significant opportunity for group-level creativity, specifically regarding construction techniques that expedited the construction process. One student described the team's approach as follows:

We were constantly offering ideas we thought would make this process more efficient. Some ideas were accepted by the group as feasible, others not so much. That's how the group worked, offer new ideas of how to do every task from lifting dirt out with buckets to jumping on cross beams to weight them down, and then some would be accepted, others not. Nothing was personal, but we were given large challenges and so any idea on how to make something easier/more efficiently should be heard.

According to Sears and Baba's ${ }^{30}$ multistage, multilevel theory of innovation, the group-level innovation was the product of:

- the team's motivation to innovate, as evidenced by the team climate and group norms;

- resources in the task domain, as evidenced by team-member exchange, the size of the team, and the diversity of the team; and

- innovation management skills, including leader commitment and constructive conflict.

These qualities were cultivated naturally within the team without formal organizational structure or leadership training. The quote above illustrates a high degree of trust amongst the team members, with participation from all members being accepted without judgment. For 
example, one student expressed, "Ideas to make tasks more efficient can always be shared, no matter how crazy because engineers are meant to think outside of the box."

Conflict naturally occurred amongst team members, and the students had to exercise conflict resolution skills, such as effective communication and patience, in order to achieve consensus in some instances. However, there was no evidence in the students' journals of social loafing, which is defined as the inclination of certain individuals to exert less effort in a team setting than they would otherwise exert individually. This is most likely due to the fact that the students had a vested interest in the project's success, i.e., the students had committed significant personal resources (time and money) and were motivated by the purpose of the bridge, as indicated in their responses to the pre-trip questions.

\section{DISCUSSION}

\section{Factors Affecting the Extent of Learning}

The degree of learning is believed to be considerable due to the intersections between the international, problem-based, and service learning experiences. A deep understanding of various technical concepts was needed for the project to succeed, and the project was carried out with limited supervision from the Bridges to Prosperity staff. The extent of learning was aided by the fact that the students assumed the primary responsibility for the bridge and were allowed to make mistakes in the field with, of course, the supervision of a trained engineer. The project involved close interactions between the students and trained professional engineers (e.g., Bridges to Prosperity staff and the team's technical mentor), allowing the students to develop an understanding of how engineering professionals solve field problems. The project was also an authentic collaborative learning experience because the students worked with each other and with members of the community to attain a common goal. Based on the benchmarks set by the National Survey of Student Engagement, ${ }^{31}$ the bridge construction project ranks highly in terms of the level of academic challenge, the enriching learning experience, the active and collaborative nature of the project, the interaction between students and faculty/professional mentors, and the supportive campus environment that allowed the project to move forward. Theory of student engagement ${ }^{32-34}$ suggests that such learning experiences lead to positive academic and personal development.

Motivation also played a significant role in the degree of learning that was observed, which is in accordance with contemporary learning theories. ${ }^{35}$ The most common reason cited for participating in such an undertaking was that students wanted to use their skills to address a significant need within a community. For example, one student commented, "I see Civil Engineering as something that can be used to help people. This project, then, is important to me because it is allowing me to engage in a meaningful project that is helping people by fundamentally meeting a need in creating access to resources for people." Analysis of the journals indicated that the students wanted to impact community as much as they wanted to perform the engineering tasks. Other motivating factors were related to the development of professional skills, specifically, technical skills, leadership skills, communication skills, and interpersonal skills. The project was viewed as a supplement to the university coursework and posed a unique opportunity to see a project through, from conception to completion. The project 
was also regarded as an opportunity to find meaning and purpose in the engineering profession, presumably an appreciation that will carry on throughout the students' careers.

\section{Relevance of the Learning Outcomes}

The bridge construction project has considerable implications for civil engineering education because of the breadth of technical skills that were fostered. Civil infrastructure projects tend to be so vast in size and scope that it is not feasible to replicate the real-world engineering experience in a classroom setting. Consequently, students spend the bulk of their time designing and analyzing components of a system without consideration for the interactions between civil engineering sub-disciplines. Additionally, students rarely (if ever) see a project through to completion. Our findings suggest that comprehensive service-learning projects in civil engineering may be useful for teaching students important skills that are not being addressed in the classroom. For example, project management skills like budgeting, sequencing, resource allocation and personnel management are concepts that may be "talked about" in the classroom, but students have limited opportunities to learn by "doing." Additionally, hands-on construction experiences are important for cultivating a "feel" for scale and engineering tolerances that is otherwise lacking.

By assuming the role as lead engineers, the students were driven to develop competency in decision-making and, more generally, to be adaptable as engineers. When asked to identify the greatest challenges in the project (Question 3), only one student cited differences between the conditions assumed in the original design and the actual conditions in the field as being one of the greatest foreseeable challenges. Yet, the evidence suggests that the students grappled with having to make decisions in the field (e.g., based on the "panic" upon arrival at the site and the desire to seek counsel from a Bridges to Prosperity engineer). When selecting a course of action, the students supported their decision with engineering calculations rather than basing the decision solely on intuition. It is important to note that this may have been the first time the students had to make an engineering decision on a project that had real-world ramifications. The adaptability that was fostered in the project will likely carry through the students' professional careers, which was suggested by one student as follows:

One thing that I hope to retain from the bridge experience is that nothing goes as $100 \%$ planned in construction. I have to go into a construction project with the knowledge that certain deadlines may not be met because of unforeseen challenges; or there may [be] more of a rush to finish a job because of these factors.

While our study has focused on a civil engineering application, adaptability (i.e., the ability to modify a design based on real-world constraints) is a skill that applies broadly to all engineering disciplines.

We also found significant evidence of creativity, global competency, cross-cultural communication, and teamwork. Our findings are consistent with prior studies on group-level innovation, ${ }^{30}$ global competency, ${ }^{19}$ and teamwork. ${ }^{29}$ To ensure cooperation between the students and the community, a service-learning project should establish a common goal that requires interdependence between the students and the community (i.e., the project should not be onesided such that only one party benefits). In the Bridges to Prosperity model, interdependence 
between the volunteers and community is aided by the establishment of a bridge construction contract that is signed by representatives from the community and the NGO. In a typical bridge construction contract, the community promises to commit labor and locally available materials, and Bridges to Prosperity provides the design, project oversight, and non-locally available materials. Collaboration between the students and the community in an international service project may be achieved as communication barriers are overcome and trust is established. We found that linguistic and cultural differences are two barriers to effective cross-cultural communication.

\section{Adequacy of the Writing Prompts}

In our research methodology, we provided writing prompts (Table I) that were designed to provide assessment data in regards to the research questions posed. These writing prompts were timed to coincide with expected milestones in the project. Questions 1-2 allowed us to assess the motivations of the students, which we believe correlate to the extent of learning. Questions 4-6 and 8 provided substantial data for the assessment of global competency and cross-cultural communication. Data in support of teamwork was obtained directly from Question 9 and indirectly from the responses to Question 7. Technical skills were assessed from responses to Questions 7 and 9-10. Question 11 provided supporting data for all of the learning outcomes that were assessed; however, Question 11 was not sufficient to gauge the breadth of learning that was evidenced by Questions 1-10. Therefore, we believe that self-reporting may not be adequate if one desires to understand the complete array of learning outcomes. Overall, we found that the reflection questions allowed us to answer our research questions, although some of the data (e.g., regarding creativity) was obtained by chance rather than as a result of the questions that were asked. Additionally, we found that the engineering students tended to focus on the technical aspects of the project and often overlooked social aspects in their reflections.

We believe that more focused reflection questions may allow for a more reliable measure of some of the non-technical skills. Data were particularly lacking in regards to the interactions between team members and the students' perceptions of the effectiveness of the team. Moreover, we did not seek to gather data on the students' perceptions regarding the economic, environmental, and social impacts of the bridge. In the pre- and post-trip reflection questions, some guidance may also be needed to ensure that the students discuss technical and nontechnical aspects of the project. In Table III, we propose revisions to the reflection questions so that teamwork, interpersonal communication skills, and perceived life cycle costs are adequately measured. Additionally, revisions to the pre- and post-trip questions are recommended to encourage reflection on the non-technical learning outcomes. These revisions may be helpful to others wishing to adapt our methodology to other types of service-learning projects.

\section{Limitations}

While our study provided significant data regarding the potential learning outcomes of international service learning projects in civil engineering, the findings cannot be generalized at this point in time due to the small sample size $(n=4)$ and the limited data collected in our study. Our focus was on a civil engineering service project involving the construction of a pedestrian bridge in Bolivia. The data presented here is specific to the events that took place, which were a 
product of the project that was carried out, the students involved, and the community in which the project took place. Nonetheless, the data presented here may allow the development of more focused reflection questions and quantitative survey tools, and the study justifies further research to better understand the learning outcomes in similar types of projects.

\section{TABLE III}

PROPOSED REFLECTION QUESTIONS (NEW QUESTIONS ARE SHOWN AS BOLD).

\begin{tabular}{|c|c|}
\hline Timing & Question \\
\hline \multirow[t]{3}{*}{ Pre-trip } & 1. Why is this project important to you? \\
\hline & $\begin{array}{l}\text { 2. What personal and professional goals have you set for yourself for this trip? What do } \\
\text { you hope to get out of this experience? }\end{array}$ \\
\hline & $\begin{array}{l}\text { 3. What are the greatest challenges that you foresee in carrying out the project? Discuss } \\
\text { both social and technical challenges. How might each challenge be addressed or } \\
\text { resolved? }\end{array}$ \\
\hline \multirow[t]{2}{*}{ Week 1} & $\begin{array}{l}\text { 4. Describe the apparent challenges that Bolivia faces in regards to the creation and } \\
\text { maintenance of infrastructure (e.g., roads, buildings, power/water supply). You can } \\
\text { frame your response in terms of construction techniques, the amount and type of } \\
\text { resources available, the quality of construction, etc. }\end{array}$ \\
\hline & $\begin{array}{l}\text { 5. What are your initial impressions of Bolivian culture and lifestyle, particularly in the } \\
\text { communities that you are working closely with? }\end{array}$ \\
\hline Week 2 & $\begin{array}{l}\text { 6. Describe your interactions with the community members, including positive and } \\
\text { negative experiences. What challenges have you encountered in regards to } \\
\text { communication and/or reaching consensus on important construction tasks? Which } \\
\text { challenges, if any, were overcome? Which ones were harder to resolve? }\end{array}$ \\
\hline \multirow[t]{2}{*}{ Week 3} & $\begin{array}{l}\text { 7. What have been the most challenging construction tasks so far? Were there any } \\
\text { differences between how you planned the construction vs. how it was actually executed } \\
\text { in the field? }\end{array}$ \\
\hline & $\begin{array}{l}\text { 8. Describe your interactions with your team members, including positive and } \\
\text { negative experiences. What challenges have you encountered in regards to } \\
\text { communication and/or reaching consensus on important construction tasks? } \\
\text { Which challenges, if any, were overcome? Which ones were harder to resolve? }\end{array}$ \\
\hline \multirow[t]{3}{*}{ Week 4} & $\begin{array}{l}\text { 9. Reflect on your initial impressions of Bolivian culture and lifestyle from your first } \\
\text { week in the country. How have your impressions evolved over your time in Bolivia? }\end{array}$ \\
\hline & $\begin{array}{l}\text { 10. Describe your greatest success (or successes) during the project's execution. How did it } \\
\text { make you feel? How did your team react? How did the community members react? }\end{array}$ \\
\hline & $\begin{array}{l}\text { 11. What are the economic, environmental, and social impacts associated with the } \\
\text { construction, use, maintenance, and decommissioning of the bridge? }\end{array}$ \\
\hline \multirow[t]{4}{*}{ Post-trip } & $\begin{array}{l}\text { 12. Reflect on your responses to the pre-trip questions regarding the importance of the } \\
\text { project, your personal and professional goals, and the challenging aspects of the } \\
\text { project. Have your views changed from your prior responses? }\end{array}$ \\
\hline & $\begin{array}{l}\text { 13. Reflect on your role as a member of the team. What was your greatest success? } \\
\text { What was your greatest frustration? What might the team do differently in the } \\
\text { future? }\end{array}$ \\
\hline & 14. Summarize what you have learned from the experience of constructing a bridge in \\
\hline & $\begin{array}{l}\text { Bolivia. What new technical and interpersonal skills have you developed? What } \\
\text { knowledge or understanding do you hope to retain in the future? }\end{array}$ \\
\hline
\end{tabular}




\section{CONCLUSIONS}

Using qualitative research methods, we analyzed the learning outcomes of an international service-learning project in civil engineering. The project provided a unique opportunity for the students to develop a range of technical and non-technical skills that are not fully addressed in traditional civil engineering curricula. Our findings support the notions that international experiences strengthen global competency and communication, real-world engineering projects improve mastery of technical skills as well as interpersonal communication skills, and service learning instills a greater understanding of the social context of engineering work. While our findings cannot be generalized at this point in time due to the small sample size and the limited data that was collected in our study, our study justifies further research to better understand the learning outcomes in similar types of service-learning projects.

\section{ACKNOWLedgMent}

This work was supported by an Investigating Student Learning Grant from the University of Michigan's Center for Research on Learning and Teaching and based upon work supported by the National Science Foundation under grant CMMI-1253440. Any opinions, findings, conclusions or recommendations are those of the authors and do not necessarily reflect the views of the sponsoring agencies. The authors also acknowledge Cindy Finelli for her consultations regarding the research.

\section{REFERENCES}

1. National Academy of Engineering. The Engineer of 2020, Washington, DC: The National Academies Press, 2004

2. Litzinger, T.A., Lattuca, L.R., Hadgraft, R.G., and Newstetter, W.C. "Engineering Education and the Development of Expertise," Journal of Engineering Education, 100, 123-150, 2011.

3. Shuman, L.J., Besterfield-Sacre, M., and McGourty, J. "The ABET 'Professional Skills' Can They Be Taught? Can They Be Assessed?" Journal of Engineering Education, 94, 4155, 2005.

4. Coyle, E.J., Jamieson, L.H., and Oakes, W.C. "EPICS: Engineering Projects in Community Service," International Journal of Engineering Education, 21, 2005.

5. Tsang, E. (Ed.). Projects that Matter: Concepts and Models for Service Learning in Engineering. American Association for Higher Education's Series on Service Learning in the Disciplines, Sterling, VA: Stylus Publishing LLC, 2007.

6. Jacoby, B. et al. Service Learning in Higher Education Concepts and Practices, San Francisco, CA: Jossey-Bass, 1996.

7. Bizjak, G. "Load Flow Network Analysis with Problem-based Learning Approach," International Journal of Electrical Engineering Education, 45, 144-151, 2008.

8. Yadav, A., Subedi, D., Lundeberg, M.A., and Bunting, C.F. "Problem-based Learning: Influence on Students' Learning in an Electrical Engineering Course," Journal of Engineering Education, 100, 253-280, 2011. 
9. Woods, D.R. "Problem-based Learning for Large Classes in Chemical Engineering," In: L. Wilkerson and H. Gijselaers (Eds.), Bringing Problem-based Learning to Higher Education, San Francisco: Jossey-Bass, pp. 91-99, 1996.

10. Barrows, H.S. "The Essentials of Problem-based Learning," Journal of Dental Education, 62, 630-633, 1998.

11. Johnson, P.A. "Problem-based Cooperative Learning in the Engineering Classroom," Journal of Professional Issues in Engineering Education and Practice, 125, 8-11, 1999.

12. Springer, L., Stanne, M.E., and Donovan, S.S. "Effects of Small-Group Learning on Undergraduates in Science, Mathematics, Engineering, and Technology: A Meta-Analysis," Review of Educational Research, 69, 21-51, 1999.

13. Savin-Baden, M. Problem-based Learning in Higher Education: Untold Stories, Philadelphia, PA: SRHE and Open University Press, 2000.

14. Hmelo-Silver, C.E. "Problem-based Learning: What and How Do Students Learn?" Educational Psychology Review, 16, 235-266, 2004.

15. Gijbels, D., Dochy, F., Van den Bossche, P., and Segers, M. "Effects of Problem-based Learning: A Meta-Analysis from the Angle of Assessment." Review of Educational Research, 75, 27-61, 2005.

16. Strobel, J., and van Barneveld, A. "When is PBL More Effective? A Meta-Synthesis of Meta-Analyses Comparing PBL to Conventional Classrooms," Interdisciplinary Journal of Problem-based Learning, 3, 44-58.

17. Haloburdo, E.P., and Thompson, M.A. "A Comparison of International Learning Experiences for Baccalaureate Nursing Students: Developed and Developing Countries, Journal of Nursing Education, 37, 13-21, 1998.

18. Mohtar, R.H., and Dare, A.E. "Global Design Team: A Global Service-Learning Experience," International Journal of Engineering Education, 28, 169-182, 2012.

19. Downey, G.L., et al. "The Globally Competent Engineer: Working Effectively with People Who Define Problems Differently," Journal of Engineering Education, 95, 107-122, 2013.

20. George, C., and Shams, A. "The Challenge of Including Customer Satisfaction Into the Assessment Criteria of Overseas Service-Learning Projects," International Journal for Service Learning in Engineering, 2, 64-75, 2007.

21. Budny, D., and Gradoville, R.T. "International Service Learning Design Projects: Educating Tomorrow's Engineers, Serving the Global Community, and Helping to Meet ABET Criterion," International Journal for Service Learning in Engineering, 6, 98-117, 2011.

22. Schaad, D.E., Franzoni, L.P., Paul, C., Bauer, A., and Morgan, K. "A Perfect Storm: Examining Natural Disasters by Combining Traditional Teaching Methods with ServiceLearning and Innovative Technology," International Journal of Engineering Education, 24, 450-465, 2008.

23. Dewoolkar, M.M., George, L., Hayden, N.J., and Rizzo, D.M. "Vertical Integration of Service-Learning into Civil and Environmental Engineering Curricula," International Journal of Engineering Education, 25, 1257-1269, 2009.

24. Jeffers, A.E., Beata, P.A., and Strassmann, B.I. "A Qualitative Study to Assess the Learning Outcomes of a Civil Engineering Service Learning Project in Bolivia," Proceedings of the ASEE Annual Conference and Exposition, Indianapolis, IN, June 15-18, 2014.

25. Bridges to Prosperity Bridges to Prosperity Bridge Manual, 2nd Ed., 2011, http://bridgestoprosperity.org/resources/technical-resources/ 
26. Borrego, M., Douglas, E.P., and Amerlink, C.T. "Quantitative, Qualitative, and Mixed Research Methods in Engineering Education," Journal of Engineering Education, 98, 53-66, 2009.

27. Giorgi, A. "Phenomenology and Experimental Psychology II," In: Giorgi, A. et al. (Eds.), Duquesne Studies in Phenomenological Psychology, Vol. I, Pittsburgh, PA: Duquesne University Press, 1975.

28. Whiting, L. "Analysis of Phenomenological Data: Personal Reflections on Giorgi's Method," Nurse Researcher, 9, 60-74, 2002.

29. Borrego, M., Karlin, J., McNair, L.D., and Beddoes, K. "Team Effectiveness Theory from Industrial and Organizational Psychology Applied to Engineering Student Project Teams: A Research Review," Journal of Engineering Education, 102, 472-512, 2013.

30. Sears, G.J., and Baba, V.V. "Toward a Multistage, Multilevel Theory of Innovation," Canadian Journal of Administrative Sciences, 28, 357-372, 2011.

31. National Survey of Student Engagement: The College Student Report - 2003 Annual Report, Bloomington, IN: Center for Postsecondary Research, Indiana University, 2003.

32. Astin, A., What Matters in College? Four Critical Years Revisited, San Francisco, CA: Jossey-Bass, 1993.

33. Light, R.J. The Harvard Assessment Seminars: Second Report, Cambridge, MA: Harvard University, 1992

34. Light, R.J., Making the Most of College, Cambridge, MA: Harvard University Press, 2001.

35. Vanasupa, L., Stolk, J., Herter, R.J. "The Four-Domain Development Diagram: A Guide for Holistic Design of Effective Learning Experiences for the Twenty-first Century Engineer," Journal of Engineering Education, 98, 67-81. 